\title{
ANTESEDEN DAN IMPLIKASI ATTITUDE TOWARD GREEN PRODUCT PADA INTENSI KONSUMEN: EKSPANSI MODEL DAN KONTEKS PRODUK MENSTRUAL CUP
}

\author{
Whony Rofianto ${ }^{1}$, Annisa Sekar Pratami ${ }^{2}$, dan Manda Sabrina ${ }^{3}$ \\ 1,2,3 STIE Indonesia Banking School, Jakarta \\ rofianto@ibs.ac.id
}

\begin{abstract}
This research is an expansion of the attitude toward green product model that has been tested in previous studies. This expansion model examines the effect of perceived value, perceived health benefits, health consciousness, environmental attitude, value orientation and eWOM on attitudes toward green products. Furthermore, the impact of continued attitude toward green products on willingness to pay and intention to recommend was also tested, as well as the impact of willingness to pay on purchase intention. This study also seeks to add to the generalization aspect of the attitude toward green product model by testing in the context of menstrual cup products as one of the green products that is still rarely studied in the marketing literature. Empirical data were collected from 99 samples of female respondents who knew about menstrual cup products, as an environmentally friendly substitute for sanitary napkins. Data were collected as primary data through a survey using an online questionnaire. Measurement model estimation and structural model estimation for hypothesis testing were carried out using the Partial Least Square Structural Equation Modeling (PLS-SEM) approach. The estimation results of the inner model indicate a positive influence of perceived value and electronic word of mouth on attitudes toward green products. Attitude toward green products has also been shown to have a positive effect on willingness to pay and intention to recommend. Furthermore, willingness to pay has also been shown to have a positive effect on purchase intention. Meanwhile, the positive influence of four other exogenous variables, namely health consciousness, environmental attitude, value orientation and perceived health benefits on attitudes toward green products was not proven in this study.
\end{abstract}

Keywords: attitude toward green product, electronic word of mouth (eWOM), purchase intention, perceived health benefit, perceived value

\begin{abstract}
Abstrak
Penelitian ini merupakan ekspansi atas model attitude toward green product yang pernah diuji pada penelitian sebelumnya. Model ekspansi ini menguji pengaruh perceived value, perceived health benefit, health consciousness, environmental attitude, value orientation serta eWOM terhadap attitude toward green product. Lebih jauh lagi, diuji pula dampak lanjutan attitude toward green product terhadap willingness to pay dan intention to recommend, serta dampak willingness to pay terhadap purchase intention. Penelitian ini juga berupaya untuk menambah aspek generalisasi atas model attitude toward green product dengan pengujian pada konteks produk menstrual cup sebagai salah satu produk hijau yang masih jarang diteliti dalam literatur pemasaran. Data empiris dihimpun dari 99 sampel responden wanita yang mengetahui produk menstrual cup, sebagai produk pengganti pembalut wanita yang ramah lingkungan. Data dihimpun sebagai data primer melalui survei dengan kuesioner daring. Estimasi model pengukuran dan estimasi model struktural untuk pengujian hipotesis dilakukan dengan pendekatan Partial Least Square Structural Equation Modelling (PLS-SEM). Hasil estimasi inner model mengindikasikan adanya pengaruh positif perceived value serta electronic word of mouth terhadap attitude toward green product. Attitude toward green product juga terbukti berpengaruh positif terhadap willingness to pay dan intention to recommend. Lebih jauh lagi, willingness to pay juga terbukti berpengaruh
\end{abstract}


positif terhadap purchase intention. Sementara itu pengaruh positif empat variabel eksogen yang lain yaitu health consciousness, environmental attitude, value orientation dan perceived health benefit terhadap attitude toward green product tidak terbukti pada penelitian ini.

Kata kunci: attitude toward green product, electronic word of mouth (eWOM), purchase intention, perceived health benefit, perceived value

\section{Pendahuluan}

Dewasa ini keadaan bumi menunjukkan sejumlah perubahan negatif, di antaranya adalah perubahan cuaca dan iklim ekstrim, dan berbagai kondisi alam lainnya yang disebabkan oleh pemanasan global dan pergeseran keseimbangan alam. Bumi berubah karena pola hidup dan kebiasaan-kebiasaan buruk yang sering dilakukan manusia yang merusak ekosistem lingkungan seperti banyaknya penggunaan produk tidak ramah lingkungan. Produk tidak ramah lingkungan adalah produk yang tidak memperhatikan akan aspek-aspek kesehatan lingkungan. Sementara produk ramah lingkungan adalah produk yang dibuat dengan memperhatikan keamanan penggunanya dan tidak menimbulkan dampak negatif bagi kesehatan pengguna nya serta tidak berpotensi merusak lingkungan (Wang et al., 2015). Sebagian masyarakat yang menyadari pentingnya upaya konsumsi yang lebih bertanggung jawab kemudian mempertimbangkan untuk memilih produk ramah lingkungan.

Sikap masyarakat terhadap penggunaan produk ramah lingkungan dapat dipengaruhi oleh sejumlah faktor seperti harga, kualitas, kinerja produk, promosi, dan implikasi kesehatan (Tan et al., 2019). Dalam perjalanannya, semakin banyak masyarakat yang sadar akan dampak lingkungan dengan berupaya mencari alternatif produk yang lebih ramah lingkungan. Salah satu diantaranya adalah produk menstrual cup sebagai substitusi yang lebih ramah lingkungan atas produk pembalut. Wanita mulai menyadari bahwa penggunaan pembalut menyumbang pada penumpukan limbah yang banyak dan sulit untuk diuraikan (Borowski, 2011). Selain itu dari perspektif kesehatan wanita, penggunaan pembalut pada wanita dapat menyebabkan pembentukan senyawa yang berpotensi menyebabkannya kanker, sindrom syok toksik, infeksi bakteri, ketidaknyamanan serta iritasi (Borowski, 2011).
Masyarakat, termasuk kelompok perempuan mulai tergerak untuk mulai peduli terhadap lingkungan dan kesehatan dengan mengkonsumsi produk yang lebih sehat atau ramah lingkungan. Fenomena ini juga dapat dikatakan mengarah pada terbentuknya pola baru kelompok konsumen yang menamakan dirinya konsumen produk hijau (Khoiriyah \& Toro, 2018). Kondisi tersebut juga didorong oleh sejumlah pemasar yang belakangan mengangkat isu lingkungan dan sustainable consumption atau konsumsi berkelanjutan (Bailey et al., 2016). Kesamaan pandangan sejumlah konsumen dan perusahaan telah mendorong sejumlah pelaku bisnis untuk berupaya memanfaatkan sumber daya yang dimilikinya untuk menciptakan produk yang ramah lingkungan (Khoiriyah \& Toro, 2018).

Pola perilaku konsumen terhadap produk ramah lingkungan telah menarik perhatian sejumlah peneliti terdahulu. Pada penelitian terdahulu, sikap terhadap produk ramah lingkungan dinilai memiliki peran penting terhadap kesediaan membayar dan niat beli atas produk ramah lingkungan (Khoiriyah \& Toro, 2018). Kesadaran akan kesehatan dan sikap terhadap lingkungan memiliki dampak positif terhadap sikap terhadap produk hijau khususnya pada produk makanan organic (Chen, 2009). Lebih jauh lagi, orientasi nilai terbukti memiliki hubungan positif terhadap sikap terhadap produk hijau (Laroche et al., 2001). Sikap terhadap produk hijau berperan penting pada kesediaan membayar, dan niat beli (Aryal et al., 2009). Sementara itu, sikap terhadap produk ramah lingkungan dapat dibangun melalui upaya menonjolkan nilai dari produk hijau dan membangun kepercayaan konsumen terhadap produk-produk hijau (Bailey et al., 2016). Meskipun telah ada sejumlah penelitian terdahulu yang membahas aspek green produk, penelitian terkait bagaimana membangun sikap positif terhadap produk ramah lingkungan dinilai masih perlu dilakukan (Khoiriyah \& Toro, 2018). 
Penelitian ini mengembangkan penelitian sebelumnya (Khoiriyah \& Toro, 2018), dengan mengekspansi model sikap terhadap produk hijau pada penelitian tersebut melalui penambahan 4 variabel baru yaitu eWOM, intention to recommend, perceived health benefit, dan perceived value. Dengan penambahan keempat konstruk tersebut, penelitian ini bertujuan menguji pengaruh perceived value, perceived health benefit, health consciousness, environmental attitude, value orientation serta eWOM terhadap attitude toward green product. Selain itu, diuji pula dampak lanjutan attitude toward green product terhadap willingness to pay dan intention to recommend, serta dampak willingness to pay terhadap purchase intention. Penelitian ini juga memberikan pembaharuan konteks penelitian berupa produk menstrual cup, di mana pada penelitian sebelumnya objek penelitian yang diangkat adalah organic food. Penelitian ini diharapkan dapat berkontribusi pada perkembangan disiplin ilmu maupun praktik pemasaran, khususnya pada bahasan pola perilaku konsumen terkait produk-produk hijau.

Health consciousness mencerminkan kesadaran seseorang akan kesehatannya dan senantiasa siap melakukan upaya-upaya menjaga kesehatan (Schifferstein \& Oude Ophuis, 1998). Individu yang memiliki kesadaran kesehatan, pada umumnya juga memperhatikan isu lingkungan yang berpotensi berdampak buruk bagi individu atau masyarakat secara luas (Ture \& Ganesh, 2012). Mereka menganggap bahwa produk organik lebih aman (Padel \& Foster, 2005). Dalam penelitian lain, di mata konsumen dengan kepedulian tinggi akan kesehatan terdapat hal yang mendorong mereka untuk menggunakan produk ramah lingkungan agar tetap sehat (Abdulsahib et al., 2019). Kesehatan menjadi hal utama bagi mereka yang melihat kelangsungan hidup jangka panjang, yang akan ditunjukkan pula dengan sikap dan perilaku menggunakan produkproduk ramah lingkungan (green product).

H1: Health consciousness berpengaruh positif terhadap attitude toward green product

\section{Environmental attitude dapat didefinisikan sebagai sikap yang} mempertimbangkan konsekuensi akan sesuatu hal pada lingkungan (Esmaeilpour \& Bahmiary, 2017). Dewasa ini, permintaan konsumen pada produk ramah lingkungan semakin meningkat. Penggunaan produk ramah lingkungan merupakan bentuk representasi dari kesadaran akan kelangsungan lingkungan hidup dibanding dengan individu yang menggunakan produk biasa (Schifferstein \& Oude Ophuis, 1998). Sikap terhadap lingkungan diasumsikan memiliki hubungan positif terhadap perilaku terhadap produk hijau (Chen, 2009).

H2: Environmental attitude berpengaruh positif terhadap attitude toward green product

Value orientation dapat dimaknai sebagai perhatian akan biaya yang dikorbankan relatif terhadap manfaat atau kualitas yang diterima (Lichtenstein et al., 1993). Bergantung dari bagaimana seorang individu memaknai nilai produk ramah lingkungan bagi dirinya, semakin tinggi orientasi nilai maka semakin tinggi pula sikap terhadap produk ramah lingkungan (Laroche et al., 2001). Jika seorang individu memaknai suatu produk hijau dapat memberikan manfaat yang cukup baik bagi dirinya dibandingkan dengan apa yang dikorbankan, sikapnya akan lebih positif terhadap produk tersebut (Khoiriyah \& Toro, 2018).

H3: Value orientation berpengaruh positif terhadap attitude toward green product

Sikap diartikan sebagai bentuk tanggapan suka atau tidak suka seorang individu bisa terhadap suatu objek, hal, tempat, atau fenomena yang terjadi (Khan \& Khan, 2006). Sikap terhadap lingkungan seseorang akan mencerminkan juga sikapnya terhadap merek hijau. Seorang konsumen yang bertekad untuk berkontribusi pada kelestarian lingkungan maka akan menunjukan sikap positif terhadap produk ramah lingkungan yang akan menghasilkan sikap positif pula pada pembelian produk ramah lingkungan (Maichum et al., 2016; Wei et al., 2017). Dalam penelitian lain juga diasumsikan bahwa konsumen akan lebih peduli terhadap 
lingkungan dengan mereka bersedia untuk membeli produk ramah lingkungan (Lai \& Cheng, 2016).

H4: Attitude toward green product berpengaruh positif terhadap willingness to pay

Willingness to pay dapat diartikan sebagai jumlah harga maksimum yang konsumen sedia bayar untuk suatu barang tertentu (Wertenbroch \& Skiera, 2002). Konsumen cenderung ingin membayar lebih pada suatu produk yang mana menurut mereka produk tersebut memiliki nilai atau manfaat tinggi di matanya (Hwang et al., 2016). Semakin besar kesediaan konsumen untuk membayar makna produk ramah lingkungan, akan semakin tinggi kemungkinan pula niat individu tersebut untuk membeli produk ramah lingkungan (Khoiriyah \& Toro, 2018). Maka dapat disimpulkan, kesediaan konsumen membayar pada produk akan mempengaruhi tingginya niat pembelian terhadap produk tersebut.

H5: Willingness to pay berpengaruh positif terhadap purchase intention

Electronic Word Of Mouth merupakan bentuk komunikasi pemasaran yang berisi tentang pernyataan positif dan negatif yang dilakukan oleh konsumen potensial melalui media internet (Hennig-Thurau et al., 2004). Internet telah menyediakan pengaturan modern untuk WOM yang menawarkan lahan subur untuk promosi elektronik dari mulut ke mulut (Kala \& Chaubey, 2018). Menginformasikan dan merekomendasikan fungsi dapat memainkan peran yang kuat karena eWOM saluran yang diatur konsumen, pengirim independen, informasi dianggap lebih terpercaya (Brown et al., 2007). Dengan lebih dipercayanya eWOM oleh konsumen pada konteks produk hijau, konsumen cenderung menentukan sikap terhadap produk hijau dengan banyaknya eWOM yang diterimanya melalui berbagai media daring.

H6: Electronic word of mouth berpengaruh positif terhadap attitude toward green product
Ketika seseorang sudah menyukai suatu produk maka secara tidak langsung akan ada niat untuk merekomendasikan kepada keluarga atau teman (Casaló et al., 2017). Individu yang menunjukan sikap positif terhadap suatu produk, akan berupaya untuk merekomendasikan kepada orang lain untuk melakukannya hal yang sama (Talukder et al., 2019). Ketika konsumen menilai manfaat yang dirasakannya dari produk ramah lingkungan, secara tidak direncanakan akan cenderung merekomendasikan produk tersebut kepada orang terdekat.

H7: Attitude toward green product berpengaruh positif terhadap intention to recommend

Seorang individu menggunakan produk organic salah satunya karena terkait dengan manfaatnya, termasuk dari sudut pandang kesehatan (H.-J. Lee \& Yun, 2015). Pemasar perlu berinvestasi dalam kejelasan produk, misalnya dari sisi manfaat kesehatan yang dirasakan konsumen terkait dengan produk (Anisimova et al., 2019). Pada saat pemasar dapat meyakinkan seorang konsumen akan manfaat kesehatan dari suatu produk hijau yang ditawarkan, akan sangat mungkin kemudian terbentuk sikap positif konsumen terhadap produk hijau tersebut.

H8: Perceived Health Benefit berpengaruh positif terhadap Attitude Toward Green Product

Perceived value dapat diartikan sebagai manfaat yang diterima melalui suatu produk dibandingkan dengan biaya yang dikorbankan untuk memperoleh produk tersebut (LeroiWerelds et al., 2014). Nilai yang dirasakan konsumen merupakan penilaian konsumen secara menyeluruh atas kegunaan produk atau layanan berdasarkan persepsi konsumen (Zeithaml, 1988). Sangat penting bagi pemasar untuk membangun persepsi di mata konsumen bahwa produk yang dikonsumsi memiliki manfaat minimal sebanding dengan pengorbanan yang diberikan (Yu et al., 2014). Jika seorang konsumen menilai bahwa suatu produk hijau memberikan manfaat yang setidaknya sama atau lebih besar dari 
pengorbanannya maka akan terbentuk pula sikap positif terhadap produk hijau tersebut.

H9: Perceived Value berpengaruh positif terhadap Attitude Toward Green Product

\section{Metodologi Penelitian}

Ekspansi model yang diajukan pada penelitian ini diuji berdasarkan data sampel responden wanita yang mengetahui produk menstrual cup, sebagai produk pengganti pembalut wanita yang ramah lingkungan. Produk menstrual cup dipilih sebagai konteks penelitian mengingat produk tersebut masih jarang dipilih sebagai konteks penelitian pada penelitian terkait produk hijau atau ramah lingkungan. Sebagai pembanding, penelitian sebelumnya yang dijadikan basis model pada penelitian ini telah menguji modelnya pada konteks makanan organik (Khoiriyah \& Toro, 2018).

Seluruh konstruk laten pada penelitian ini dioperasionalisasikan dalam bentuk multiitem scale dengan pernyataan indikator yang diadopsi dari sejumlah penelitian terdahulu yang relevan sebagaimana ditampilkan pada Tabel 1. Seluruh indikator konstruk dituangkan dalam suatu format kuesioner daring menggunakan pola skala Likert dengan rentang skala jawaban antara $1=$ Sangat tidak setuju hingga $7=$ Sangat setuju. Data dihimpun melalui survei yang dilakukan secara online kepada wanita yang berusia mulai dari 16 tahun keatas menggunakan kuesioner daring yang telah dipersiapkan.

Pengujian hipotesis berdasarkan data empiris yang berhasil dihimpun dilakukan dengan pendekatan PLS-SEM yang memungkinkan identifikasi konstruk-konstruk pendorong variabel endogen pada model kompleks dengan kebutuhan jumlah data minimum yang tidak besar data yang tidak selalu berdistribusi normal (Hair et al., 2017). Dengan nilai $\mathrm{R}^{2}$ terkecil hasil estimasi sebesar 0.334 dan jumlah panah menuju salah satu konstruk endogen paling banyak adalah 4 maka kebutuhan data minimum untuk pengujian hipotesis adalah sebanyak 65 sampel (Ali et al., 2018).

\section{Hasil dan Pembahasan}

Melalui proses penyebaran kuesioner secara daring diperoleh 99 data responden Indonesia yang memenuhi syarat, yaitu wanita yang mengetahui produk menstrual cup, sebagai produk pengganti pembalut wanita yang ramah lingkungan. Jumlah ini sudah melebihi nilai kebutuhan sampel minimum untuk model yang diajukan dengan $\mathrm{R}^{2}$ terkecil 0.542 yaitu sebesar 48 sampel, untuk mencapai statistical power 0.8 dan level of significance 0.05 (Ali et al., 2018). Umur responden bervariasi pada rentang 16 hingga 51 tahun, dengan 73.7 persen berpendidikan S1/D4.

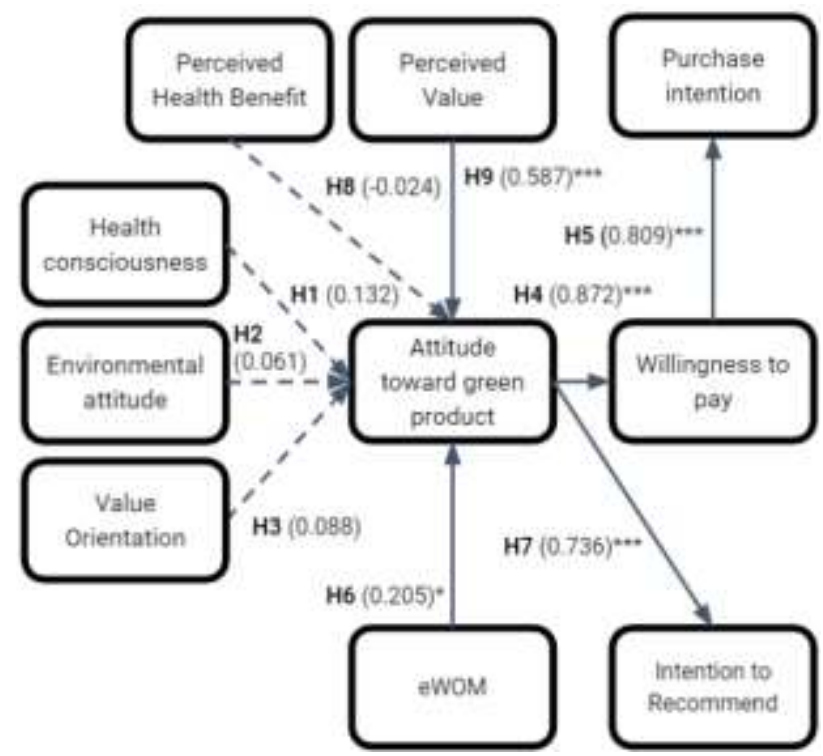

Catatan: nilai dalam kurung adalah koefisien regresi, $* p<0.05, * * p<0.01, * * * p<0.001$

Gambar 1

Model Penelitian dan Hasil Estimasi Inner Model

Seluruh nilai muatan faktor atas masingmasing indikator pengukuran berada di atas 0.7, dengan nilai Average Variance Extracted (AVE) untuk masing-masing konstruk berada di atas nilai 0.5 , hal ini berarti secara keseluruhan model pengukuran yang dipergunakan memiliki derajat convergent validity yang baik. Seluruh nilai Cronbach a untuk masing-masing konstruk berada di atas 0.7, yang mengindikasikan bahwa model pengukuran pada penelitian ini memiliki derajat internal consistency reliability yang baik. Hasil estimasi Fornell-Larcker criterion mengindikasikan 
bahwa seluruh nilai akar kuadrat AVE masingmasing konstruk lebih tinggi dari nilai korelasi konstruk tersebut dengan konstruk lain. Hal ini berarti model penelitian yang diuji memiliki derajat discriminant validity yang baik.

Hasil estimasi model penelitian menghasilkan nilai $\mathrm{R}^{2}$ untuk masing-masing variabel endogen dengan satu prediktor sebesar 0.542 untuk intention to recommend, 0.760 untuk willingness to pay serta 0.654 untuk purchase intention. Sementara itu nilai adjusted $\mathrm{R}^{2}$ untuk attitude toward green product sebagai variabel endogen dengan lebih dari 1 prediktor adalah 0.655. Nilai koefisien determinasi $R^{2} 0.20$ atau lebih dinilai relatif tinggi pada penelitian terkait perilaku konsumen (Hair et al., 2017).

Hasil estimasi model struktural mengindikasikan adanya pengaruh positif signifikan electronic word of mouth $(\beta=0.205$, $\rho<0.05)$ dan perceived value $(\beta=0.587$, $\rho<0.05)$ terhadap attitude toward green product yang berarti mendukung $\mathrm{H} 6$ dan $\mathrm{H} 9$. Hasil estimasi juga menunjukkan adanya pengaruh positif signifikan attitude toward green product terhadap willingness to pay $(\beta=0.872, \quad \rho<0.05)$ dan intention to recommend $(\beta=0.736, \rho<0.05)$ yang berarti mendukung $\mathrm{H} 4$ dan $\mathrm{H} 7$. Lebih jauh lagi, willingness to pay menunjukkan efek positif signifikan terhadap purchase intention $(\beta=0.809, \rho<0.05)$, yang berarti H5 terbukti pada penelitian ini. Sementara itu, tiga hipotesis lain terkait variabel eksogen yang diajukan yaitu $\mathrm{H} 1, \mathrm{H} 2, \mathrm{H} 3$ dan $\mathrm{H} 8$ tidak terbukti menunjukkan adanya gejala pengaruh yang signifikan antara konstruk health consciousness, environmental attitude, value orientation dan perceived health benefit terhadap attitude toward green product.

Pada penelitian ini, tiga variabel eksogen yang diajukan dan terbukti pada penelitian sebelumnya yaitu health consciousness, environmental attitude, value orientation tidak menunjukkan adanya bukti pengaruh yang signifikan terhadap attitude toward green product. Hal ini kemungkinan karena objek yang digunakan berbeda. Pada penelitian sebelum nya menggunakan makanan organik sebagai objek penelitian. Makanan organik telah lebih lama dibicarakan baik melalui edukasi dari para ahli di bidangnya atau pemasar kepada konsumen. Sementara itu, pada penelitian ini menstrual cup sebagai objek kajian merupakan produk yang tergolong baru yang belum lama mengalami proses pembicaraan dan edukasi di kalangan calon penggunanya. Implikasinya, masih terdapat pola yang sangat beragam terkait bagaimana calon pengguna mempersepsikan aspek health consciousness, environmental attitude, value orientation yang kemudian dikaitkan dengan attitude toward green product, dalam hal ini adalah produk menstrual cup. Jika kedepannya proses edukasi kepada calon pengguna meningkat, ditambah kualitas dan nilai produk yang mungkin dapat semakin ditingkatkan, khususnya yang menyangkut aspek kesehatan dan keramahan terhadap lingkungan, bisa jadi pola hubungan tiga hipotesis tersebut dapat terlihat.

Dua dari tiga variabel eksogen yang diikutsertakan pada model yaitu perceived value dan electronic word of mouth terbukti menunjukkan adanya pengaruh positif terhadap attitude toward green product. Hal ini berarti, penting dipertimbangkan oleh pengelola merek produk menstrual cup atau sejenisnya untuk mengupayakan langkahlangkah komunikasi pemasaran secara berkesinambungan untuk mengedukasi konsumen terkait value, bahwa manfaat yang ditawarkan oleh produk tersebut sepadan dengan harga belinya yang mungkin relatif lebih mahal daripada produk konvensional yang ada saat ini namun diiringi dengan kelebihannya yang dapat dipergunakan ulang dalam kurun waktu yang relatif lama. Pengelola merek juga perlu mengupayakan adanya word of mouth positif secara organik dari konsumen yang telah menggunakan produk tersebut dengan cara senantiasa mempertahankan dan meningkatkan kualitas produk yang ditawarkan, serta mengupayakan adanya word of mouth positif dari para public figure dan opinion leader khususnya di fase awal pengenalan produk sebelum mulai terbentuknya word of mouth positif secara organik dari konsumen yang telah menggunakan produk tersebut. Kedua upaya ini diharapkan dapat meningkatkan attitude toward green product yang kemudian berdampak baik berupa meningkatnya willingness to pay dan intention to recommend 
dari calon konsumen maupun konsumen yang sudah ada. Sementara itu, terkait dengan perceived health benefit yang tidak terbukti berdampak pada attitude toward green product pada penelitian ini mengindikasikan bahwa belum adanya keseragaman pemahaman akan manfaat kesehatan produk menstrual cup, misalnya masalah higenitasnya pada pemakaian yang berulang. Pengelola merek perlu menempuh upaya meningkatkan hal ini dengan terus berinovasi pada aspek manfaat kesehatan produk menstrual cup serta mengedukasi pasar terkait dengan hal tersebut.

\section{Simpulan}

Penelitian ini menunjukkan hasil yang menarik bagi khasanah ilmu pengetahuan maupun praktik manajerial pemasaran khususnya pada bahasan produk menstrual cup sebagai salah satu bentuk produk hijau. Penelitian ini mengungkap adanya keberagaman persepsi konsumen yang cukup lebar terkait dengan aspek kesehatan dan keramahannya terhadap lingkungan. Dampaknya, sejumlah faktor terkait persepsi konsumen pada aspek kesehatan dan keramahan lingkungan belum terlihat secara signifikan dapat membentuk sikap positif konsumen terhadap produk tersebut. Hal ini merupakan tantangan bagi kalangan manajerial produk menstrual cup atau sejenisnya sebagai salah satu produk hijau untuk terus berinovasi dan mengedukasi pasar agar lebih dapat meyakinkan konsumen akan keunggulan produk pada aspek kesehatan dan keramahan lingkungan dibandingkan dengan produk konvensionalnya yang sudah ada selama ini.

Terlepas dari kontribusi akademis dan praktis yang coba disumbangkan, penelitian ini memiliki keterbatasan penelitian yang membuka peluang bagi penelitian lebih lanjut. Secara umum penelitian ini masih cenderung pada fase eksplorasi awal, khususnya pada konteks menstrual cup sebagai salah satu bentuk produk hijau. Penelitian lebih lanjut di masa mendatang pada saat pasar sudah lebih teredukasi, lebih aware dan inovasi produk dapat terus dilakukan, diharapkan dapat memvalidasi temuan pada penelitian ini. Penelitian dengan rentang usia responden yang lebih sempit, atau pada konteks negara lain dengan tingkat edukasi, kebiasaan dan budaya yang berbeda juga diharapkan dapat memvalidasi ulang hasil penelitian ini.

\section{Daftar Pustaka}

Abdulsahib, J. S., Eneizan, B., \& Alabboodi, A. S. (2019). Environmental Concern, Health Consciousness and Purchase Intention of Green Products: An Application of Extended Theory of Planned Behavior. The Journal of Social Sciences Research, 54, 1203-1215. https://doi.org/10.32861/jssr.54.1203.1 215

Anisimova, T., Mavondo, F., \& Weiss, J. (2019). Controlled and uncontrolled communication stimuli and organic food purchases: The mediating role of perceived communication clarity, perceived health benefits, and trust. Journal of Marketing Communications, 25(2), 180-203. https://doi.org/10.1080/13527266.2017 .1387869

Aryal, K. P., Chaudhary, P., Pandit, S., \& Sharma, G. (2009). Consumers' Willingness to Pay for Organic Products: A Case From Kathmandu Valley. Journal of Agriculture and Environment, 10, 1526. https://doi.org/10.3126/aej.v10i0.2126

Bailey, A. A., Mishra, A., \& Tiamiyu, M. F. (2016). GREEN consumption values and Indian consumers' response to marketing communications. Journal of Consumer Marketing, 33(7), 562-573. https://doi.org/10.1108/JCM-12-20151632

Borowski, A. (2011). Are American women turning to reusable and greener menstrual products due to health and environmental pollution concerns? Theses.

https://scholarworks.rit.edu/theses/544

Brown, J., Broderick, A. J., \& Lee, N. (2007). Word of mouth communication within online communities: Conceptualizing the online social network. Journal of Interactive Marketing, 21(3), 2-20. https://doi.org/10.1002/dir.20082 
Campbell, J., DiPietro, R. B., \& Remar, D. (2014). Local foods in a university setting: Price consciousness, product involvement, price/quality inference and consumer's willingness-to-pay. International Journal of Hospitality Management, 42, 39-49. https://doi.org/10.1016/j.ijhm.2014.05. 014

Casaló, L. V., Flavián, C., \& Ibáñez-Sánchez, S. (2017). Antecedents of consumer intention to follow and recommend an Instagram account. Online Information Review, 41(7), 1046-1063. https://doi.org/10.1108/OIR-09-20160253

Chen, M. (2009). Attitude toward organic foods among Taiwanese as related to health consciousness, environmental attitudes, and the mediating effects of a healthy lifestyle. British Food Journal, 111(2), 165-178.

https://doi.org/10.1108/000707009109 31986

De Toni, D., Eberle, L., Larentis, F., \& Milan, G. S. (2018). Antecedents of Perceived Value and Repurchase Intention of Organic Food. Journal of Food Products Marketing, 24(4), 456-475. https://doi.org/10.1080/10454446.2017 .1314231

Esmaeilpour, M., \& Bahmiary, E. (2017). Investigating the impact of environmental attitude on the decision to purchase a green product with the mediating role of environmental concern and care for green products. Management \& Marketing, 12(2), 297315. https://doi.org/10.1515/mmcks2017-0018

Han, H., Hsu, L.-T. (Jane), \& Lee, J.-S. (2009). Empirical investigation of the roles of attitudes toward green behaviors, overall image, gender, and age in hotel customers' eco-friendly decision-making process. International Journal of Hospitality Management, 28(4), 519528.

https://doi.org/10.1016/j.ijhm.2009.02. 004

Hennig-Thurau, T., Gwinner, K. P., Walsh, G., \& Gremler, D. D. (2004). Electronic word-of-mouth via consumer-opinion platforms: What motivates consumers to articulate themselves on the Internet? Journal of Interactive Marketing, 18(1), 38-52. https://doi.org/10.1002/dir.10073

Hwang, J., Lee, K., \& Lin, T.-N. (2016). Ingredient labeling and health claims influencing consumer perceptions, purchase intentions, and willingness to pay. Journal of Foodservice Business Research, 19(4), 352-367. https://doi.org/10.1080/15378020.2016 .1181507

Kala, D., \& Chaubey, D. S. (2018). The effect of eWOM communication on brand image and purchase intention towards lifestyle products in India. International Journal of Services, Economics and Management, $\quad$ (2), 143. https://doi.org/10.1504/IJSEM.2018.09 6077

Kemp, E., \& Bui, M. (2011). Healthy brands: Establishing brand credibility, commitment and connection among consumers. Journal of Consumer Marketing, 28(6), 429-437. https://doi.org/10.1108/073637611111 65949

Khan, K. M., \& Khan, M. N. (2006). The encyclopaedic dictionary of marketing. Response Books.

Khoiriyah, S., \& Toro, M. J. S. (2018). Attitude Toward Green Product, Willingness to Pay and Intention to Purchase. International Journal of Business and Society, 19, 620-628.

Kim, H., Lee, E.-J., \& Hur, W.-M. (2012). The Normative Social Influence on EcoFriendly Consumer Behavior: The Moderating Effect of Environmental Marketing Claims. Clothing and Textiles Research Journal, 30(1), 4-18. https://doi.org/10.1177/0887302X1244 0875

Kim, Y. (2011). Understanding Green Purchase: The Influence of Collectivism, Personal Values and Environmental Attitudes, and the Moderating Effect of Perceived Consumer Effectiveness. Seoul Journal of Business, 171), 6592. 
https://doi.org/10.35152/SNUSJB.2011. 17.1.003

Konuk, F. A. (2018). Antecedents of pregnant women's purchase intentions and willingness to pay a premium for organic food. British Food Journal, 120(7), 1561-1573. https://doi.org/10.1108/BFJ-11-20170631

Lai, C. K. M., \& Cheng, E. W. L. (2016). Green purchase behavior of undergraduate students in Hong Kong. The Social Science Journal, 53(1), 67-76. https://doi.org/10.1016/j.soscij.2015.11 .003

Laroche, M., Bergeron, J., \& Barbaro-Forleo, G. (2001). Targeting consumers who are willing to pay more for environmentally friendly products. Journal of Consumer Marketing, 18(6), 503-520. https://doi.org/10.1108/EUM000000000 6155

Lee, H.-J., \& Yun, Z.-S. (2015). Consumers' perceptions of organic food attributes and cognitive and affective attitudes as determinants of their purchase intentions toward organic food. Food Quality and Preference, 39, 259-267. https://doi.org/10.1016/j.foodqual.2014 .06 .002

Lee, J.-S., Hsu, L.-T. (Jane), Han, H., \& Kim, Y. (2010). Understanding how consumers view green hotels: How a hotel's green image can influence behavioural intentions. Journal of Sustainable Tourism, 18(7), 901-914. https://doi.org/10.1080/096695810037 77747

Leroi-Werelds, S., Streukens, S., Brady, M. K., \& Swinnen, G. (2014). Assessing the value of commonly used methods for measuring customer value: A multisetting empirical study. Journal of the Academy of Marketing Science, 42(4), 430-451.

https://doi.org/10.1007/s11747-0130363-4

Lichtenstein, D. R., Ridgway, N. M., \& Netemeyer, R. G. (1993). Price Perceptions and Consumer Shopping Behavior: A Field Study. JOURNAL OF MARKETING RESEARCH, 12.
Maichum, K., Parichatnon, S., \& Peng, K.-C. (2016). Application of the Extended Theory of Planned Behavior Model to Investigate Purchase Intention of Green Products among Thai Consumers. Sustainability, $\quad 8(10), \quad 1077$. https://doi.org/10.3390/su8101077

Mohd Suki, N. (2016). Green product purchase intention: Impact of green brands, attitude, and knowledge. British Food Journal, 118(12), 2893-2910. https://doi.org/10.1108/BFJ-06-20160295

Oliveira, T., Thomas, M., Baptista, G., \& Campos, F. (2016). Mobile payment: Understanding the determinants of customer adoption and intention to recommend the technology. Computers in Human Behavior, 61, 404-414. https://doi.org/10.1016/j.chb.2016.03.0 30

Padel, S., \& Foster, C. (2005). Exploring the gap between attitudes and behaviour: Understanding why consumers buy or do not buy organic food. British Food Journal, 1078), 606-625. https://doi.org/10.1108/000707005106 11002

Perceived Health Benefits and Soy Consumption Behavior: Two-Stage Decision Model Approach Authors(s): Wanki Moon, Siva K. Balasubramanian and Arbindra Rimal. (2005). Journal of Agricultural and Resource Economics, 30(2), 315-332.

Perera, C. H., Nayak, R., \& Nguyen, L. T. V. (2021). The impact of subjective norms, eWOM and perceived brand credibility on brand equity: Application to the higher education sector. International Journal of Educational Management, 35(1), $63-74$. https://doi.org/10.1108/IJEM-05-20200264

Prayag, G., Hosany, S., Muskat, B., \& Del Chiappa, G. (2017). Understanding the Relationships between Tourists' Emotional Experiences, Perceived Overall Image, Satisfaction, and Intention to Recommend. Journal of Travel Research, 56(1), 41-54. 
https://doi.org/10.1177/004728751562 0567

Schifferstein, H. N. J., \& Oude Ophuis, P. A. M. (1998). Health-related determinants of organic food consumption in The Netherlands. Food Quality and Preference, 9(3), 119-133. https://doi.org/10.1016/S09503293(97)00044-X

Sun, Y., \& Wang, S. (2019). Understanding consumers' intentions to purchase green products in the social media marketing context. Asia Pacific Journal of Marketing and Logistics, 32(4), 860878. https://doi.org/10.1108/APJML-032019-0178

Talukder, M. S., Chiong, R., Bao, Y., \& Hayat Malik, B. (2019). Acceptance and use predictors of fitness wearable technology and intention to recommend: An empirical study. Industrial Management \& Data Systems, 119(1), 170-188. https://doi.org/10.1108/IMDS-01-20180009

Tan, C. N. L., Ojo, A. O., \& Thurasamy, R. (2019). Determinants of green product buying decision among young consumers in Malaysia. Young Consumers, 20(2). https://doi.org/10.1108/YC-12-20180898

Ture, R. S., \& Ganesh, M. P. (2012). Effect of Health Consciousness and Material Values on Environmental Belief and Proenvironmental Behaviours. International Proceedings of Economics Development and Research, 43, 41-45.

Wang, X., Chan, H. K., \& Li, D. (2015). A case study of an integrated fuzzy methodology for green product development. European Journal of Operational Research, 241(1), 212-223. https://doi.org/10.1016/j.ejor.2014.08.0 07

Wei, C., Chiang, C., Kou, T., \& Lee, B. C. Y. (2017). Toward Sustainable Livelihoods: Investigating the Drivers of Purchase Behavior for Green Products. Business Strategy and the Environment, 26(5), 626-639.

https://doi.org/10.1002/bse.1942
Wertenbroch, K., \& Skiera, B. (2002). Measuring Consumers' Willingness to Pay at the Point of Purchase. Journal of Marketing Research, 39(2), 228-241. https://doi.org/10.1509/jmkr.39.2.228.1 9086

Yadav, R., \& Pathak, G. S. (2016). Intention to purchase organic food among young consumers: Evidences from a developing nation. Appetite, 96, 122128.

https://doi.org/10.1016/j.appet.2015.09 .017

Yu, H. S., Zhang, J. J., Kim, D. H., Chen, K. K., Henderson, C., Min, S. D., \& Huang, $H$. (2014). Service Quality, Perceived Value, Customer Satisfaction, and Behavioral Intention Among Fitness Center Members Aged 60 Years and Over. Social Behavior and Personality: An International Journal, 42(5), 757767.

https://doi.org/10.2224/sbp.2014.42.5. 757

Zeithaml, V. A. (1988). Consumer Perceptions of Price, Quality, and Value: A MeansEnd Model and Synthesis of Evidence. Journal of Marketing, 52(3), 2-22. https://doi.org/10.1177/002224298805 200302 